Published by LPMP Imperium

Journal homepage: https:/ / ejournal.imperiuminstitute.org/index.php/ AKURASI

\title{
Pengendalian Internal Pada Perusahaan Start Up
}

\author{
Regita M Farhana, Ludwina Harahap \\ Universitas Trilogi, Jakarta, Indonesia
}

\begin{abstract}
Internal Control System is one of the tools for management to control all operational activities in line to achieve ultimate goals. As a start-up company, internal control is a must. This research conduct to analyzes internal control systems in handling inventory of vegetables and fruit-based on COSO (Committee of Sponsoring Organization) theory. This type of research is a qualitative descriptive approach. Data is obtained through interviews with informants. The results showed that the company has largely implemented internal controls on vegetable and fruit inventory that according to internal control standards according to COSO. But, it is not fully implemented for environmental control and supervision activities..
\end{abstract}

\section{Keywords:}

Internal Control, Start Up, Inventory, COSO

\section{Corresponding Author:}

Ludwina Harahap, Universitas Trilogi.Jl. TMP. Kalibata

Jakarta Selatan 12760,

DKI Jakarta, Indonesia

Email: ludyhara@trilogi.ac.id

(c) The Author(s) 2020

DOI: https:/ / doi.org/ 10.36407/ akurasi.v2i3.242

\section{Research Paper \\ Accounting and Auditing}

Received: 30 Sep 2020

Revised: 20 Oct 2020

Accepted: 05 Dec 2020

Online: 20 Dec 2020

Akurasi: Jurnal Riset Akuntansi dan Keuangan, Vol 2, No.3, 2020, pp. $137-148$

eISSN 2685-2888

\section{(C) (2)}

CC BY: This license allows reusers to distribute, remix, adapt, and build upon the material in any medium or format, so long as attribution is given to the creator. The license allows for commercial use. 


\section{PENDAHULUAN}

Persediaan merupakan bagian penting dalam kegiatan operasional terutama perusahaan manufaktur dan dagang, tidak terkecuali perusahaan startup yang menjual persediaan untuk mencapai tujuan akhir perusahaan yaitu memperoleh laba. Salah satu startup yang berkembang saat ini adalah startup toko online yang menjual sayur dan buah melalui aplikasi. Persediaan sayur dan buah ini diperoleh langsung dari petani, sehingga kualitas kesegaran sayur dan buah dapat terjaga.

Data BPS 10 tahun terakhir menunjukkan terdapat penurunan pendapatan petani, yang disebabkan oleh para tengkulak. Umumnya hasil pertanian didistribusikan langsung ke pasar, namun, adanya tengkulak (pengepul) maka petani menjual sayur dan buah dengan harga murah sehingga menyebabkan petani menderitakerugian. Perkembangan teknologi di bidang bisnis dengan munculnya e-commercetentu sangat membantu petani untuk memasarkan hasil pertaniannya dan meningkatkan pendapatan petani.

Pengendalian dalam pengelolaan aktivitas perusahaan dagang sangatpenting. Salah satu yang perlu diperhatikan adalah pengendalian atas aktivitas pengelolaan persediaan barang dagang. Menurut Stice et al. (2009:572), persediaan merupakan bagian paling aktif dalam operasi perusahaan yang secara terus menerus dibeli, diproduksi dan dijual. Hal ini membuat perusahaan dagang harus melakukan penanganan dan pengawasan terhadap persediaan dengan melakukan pengendalian. Terutama untuk persediaan yang rentan terhadap tingkat ketahanannya, seperti sayur dan buah. Warren et al. (2015: 453) mengatakan bahwa pengendalian atas persediaan harus segera dimulai setelah persediaan diterima. Pengendalian dilakukan untuk mencegah kerusakan, pencurian atau kecurangan dan lainnya.

Persediaan sangat rentan terhadap kerusakan maupun kecurangan. Kerusakan umumnya terjadi ketikaproses pemasukan atau penerimaan barang yang tidak benar, lalai dalam melakukan pencatatan permintaan barang, barang yang dikeluarkan tidak sesuai pesanan, serta kemungkinan lainnya dapat menyebabkan catatan persediaan berbeda dengan persediaan yang sebenarnya ada di gudang. Dalam mencegah hal itu, maka diperlukan pengendalian internal persediaan yang bertujuan untuk melindungi aset perusahaan dan informasi mengenai persediaan lebih akurat dan dapat dipercaya.Pengendalian internal persediaan dapat dilakukan dengan melakukan tindakan pengamanan untuk mencegah kerusakan, kecurangan, maupun tindakan penyimpangan lainnya. Persediaan dan biaya atas kelebihan persediaan merupakan hal yang penting dalam menentukan profitabilitas perusahaan.

Toko online sayurmayur adalah bisnis start-up melaluie-commerce yang menyediakan buah dan sayur segar berkualitas dari petani lokal Indonesia. Saat ini toko online sayur mayur berfokus untuk menyediakan bahan segar organik, bebas pestisida, hidroponik, dan berkualitas tinggi. Toko online sayurmayur memiliki konsep farm-to-table, dimana buah dan sayuran dikirim langsung kepada konsumen setelah dipanen oleh petani mitra toko online sayurmayur di hari yang sama. Masalah yang timbul yaitu, pertama adalah sayur dan buah yang tidak terjual (barang waste) ke konsumen akibat produk tidak memenuhi kualifikasi seperti rusak, busuk, layu dan sebagainya. Kedua, persedian barang dagangan yang cacat seperti berubah warna pada sayur dan buah, adannya kutu buah, dan sebagainya (semi waste) sehingga tidak bisa dijual ke konsumen yang memesan melalui sistem online. Hal ini tentunya akan mengakibatkan kerugian bagi perusahaan. Untuk mengurangi permasalahan 
tersebut, diperlukan penanganan terhadap persediaan sayur dan buah yaitu pengendalian internal.

Untuk menghindari kerugian tersebut, perusahaan perlu menerapkan praktek pengendalian internal yang memadai. Studi ini dilakukan untuk menganalisis pelaksanaan pengendalian internal terhadap persediaan sayur dan buah berdasarkan standar Committee of Sponsoring Organization (COSO). Studi dan literatur sejenis masih jarang dilakukan dan ditemukan di Indonesia mengingat praktek e-commerce merupakan bisnis yang baru muncul beberapa tahun belakangan ini. Studi pengendalian internal telah dilakukan diberbagai proses bisnis namun belum terlalu banyak literatur yang membahas pengendalian internal persedian untuk produk sayur mayor. Obyek penelitian merupakan suatu perusahaan asli Indonesia yang dibangun dengan konsep, visi dan misi memajukan petani di Indonesia. Kontribusi dari studi ini diharapkan dapat menambah literatur dalam bidang kajian pengendalian internal.

\section{KAJIAN PUSTAKA}

\section{Sistem}

Sistem adalah serangkaian dua atau lebih komponen yang saling terkait dan berinteraksi untuk mencapai tujuan" (Romney, Marshall B. dan Steinbart, Paul John Steinbart : 2015). Sedangkan menurut Libby, Libby \& Short dalam penelitian Amanda, (2015), menyatakan bahwa akuntansi (accounting) merupakan sebuah sistem yang mengumpulkan dan memproses (menganalisis, menghitung, dan mencatat) informasi keuangan mengenai sebuah organisasi dan melaporkan informasi tersebut kepada pengambil keputusan. .

\section{Pengendalian Internal}

Pengendalian internal merupakan suatu cara untuk mengarahkan, mengawasi, dan mengukur sumber daya. Pengendalian ini berperan penting untuk mencegah dan mendeteksi kecurangan (fraud). Menurut Committee of Sponsoring Organization (COSO) (2013), pengendalian internal adalah suatu proses yang dilakukan oleh dewan direksi, manajemen dan personal lainnya dirancang untuk memberi keyakinan memadai tentang pencapaian tujuan yang berkaitan dengan operasi (operations), pelaporan (reporting), dan kepatuhan (compliance).

\section{Komponen Pengendalian Internal}

Kerangka pengendalian internal yang paling banyak diterima di A.S. dikeluarkan oleh COSO. Komponen pengendalian internal COSO, Arens (2013) dalam penelitian Yuliandes, sebagai berikut:

\section{Lingkungan Pengendalian}

Lingkungan pengendalian internal terdiri dari tindakan, kebijakan dan prosedur menggambarkan keseluruhan sikap manajemen, direksi, dan pemilik dari suatu entitas atas pengendalian internal dan pentingnya pengendalian internal tersebut terhadap entitas. Untuk memahami dan menilai lingkungan pengendalian, ada beberapa elemen penting antara lain:
a. Integritas dan nilai etika.
b. Komitmen terhadap Kompetensi.
c. Partisipasi Dewan Direksi dan Komisaris Komite Audit
d. Filosofi Manajemen dan Gaya Operasi
e. Struktur Organisasi 


\section{Penilaian Resiko}

Menilai resiko merupakan komponen kedua dari pengendalian internal. Penilaian resiko merupakan kegiatan yang dila-kukan oleh manajemen dalam mengidentifikasi dan menganalisis resiko yang menghambat perusahaan dalam mencapai tujuan. COSO (2013) menyatakan empat prinsip yang mendukung penilaian risiko, yaitu:

a. Organisasi menetapkan tujuan dengan kejelasan yang tepat untuk memungkinkan identifikasi dan penilaian risiko.

b. Organisasi mengidentifikasi risiko pencapaian tujuan di seluruh entitas dan menganalisa risiko sebagai dasar untuk menentukan bagaimana risiko harus dikelola.

c. Organisasi mempertimbangkan potensi terjadinya fraud atau kecurangan dalam menilai risiko terhadap pencapaian tujuan.

d. Organisasi mengidentifikasi dan mengevaluasi perubahan yang dapat mempengaruhi sistem pengendalian internal secara signifikan.

\section{Aktivitas Pengendalian}

Dalam Committee of Sponsoring Organization (COSO, 2013), terdapat tiga prinsip yang berkaitan dengan aktivitas pengendalian antara lain:

a. Mengembangkan Aktivitas Pengendalian

b. Mengembangkan Kontrol Umum Atas Teknologi

c. Merinci ke dalam Kebijakan dan Prosedur

\section{Informasi dan Komunikasi}

Terdapat tiga prinsip dalam COSO (2013) dalam penerapan pengendalian internal untuk mendukung informasi dan komunikasi lebih baik, yaitu:

a. Organisasi mendapatkan informasi yang berkualitas dan relevan untuk mendukung fungsi seluruh komponen pengendalian internal.

b. Organisasi mengkomunikasikan informasi secara internal, termasuk tujuan dan tanggung jawab pengendalian internal yang diperlukan untuk mendukung fungsi pengendalian internal.

c. Organisasi berkomunikasi dengan pihak luar mengenai hal terkait dengan berbagai hal yang dapat mempengaruhi berfungsinya seluruh komponen pengendalian internal.

Pengawasan

Terdapat dua prinsip dalam penerapan pengendalian internal yang mendukung komponen Pengawasan (monitoring) lebih baik, yaitu:

a. Organisasi memilih mengem-bangkan dan melakukan evaluasi berkelanjutan dan terpisah untuk memastikan apakah komponen pengendalian internal berfungsi dengan baik.

b. Organisasi mengevaluasi dan mengkomunikasikan kekurangan. Pengendalian internal secara tepat waktu kepada pihak-pihak yang bertanggung jawab untuk mengambil tindakan korektif, termasuk manajemen senior dan dewan direksi.

\section{Persediaan Barang Dagang}

Menurut PSAK 14 (Revisi 2015) Persediaan meliputi barang yang dibeli dan disimpan untuk dijual kembali. Misalnya, barang dagang dibeli oleh pengecer untuk dijual kembali. Menurut 
Alexandri (2010), Persediaan merupakan suatu aktiva yang meliputi barang milik perusahaan untuk dijual dalam suatu periode usaha tertentu dan persediaan barang yang masih dalam pengerjaan serta proses produksi ataupun persediaan bahan baku yang menunggu penggunaannya dalam proses produksi. Adapun jenis-jenis persediaan diantarannya:

a. Bath Stock/ Lot Size Inventory

Bath stock/ Lot size inventory adalah persediaan yang diadakan karena kita membeli atau membuat bahan-bahan atau barang-barang dalam jumlah yang lebih besar daripada jumlah yang dibutuhkan pada saat itu.

b. Fluctuation Stock

Fluctuation Stock adalah persediaan yang diadakan untuk menghadapi fluktuasi permintaan konsumen yang tidak dapat di prediksi.

c. Anticipation Stock

Anticipation Stock adalah persediaan diadakan untuk menghadapi fluktuasi permintaan yang dapat diprediksi berdasarkan pola musiman.

\section{METODE PENELITIAN}

\section{Jenis Penelitian}

Jenis penelitian adalah penelitian kualitatif. Pendekatan penelitian yang digunakan dalam penelitian ini adalah deskriptif kualitatif. Penelitian yang mengumpulkan data melalui wawancara dari objek yang diteliti sebagai sumber langsung dengan instrumen penelitian (Sugiyono, 2017).

\section{Objek dan Sumber Data Penelitian}

Objek dalam penelitian ini adalah Toko online sayur mayur yang berlokasi dijakarta Selatan.

Data penelitian yang digunakan dalam penelitian ini adalah data primer. Data primer merupakan data yang belum diolah. Sumber data diperoleh secara langsung dari pihak terkait. Untuk mendapatkan data tersebut, penulis melakukan wawancara langsung kepada pihak terkait.

\section{Teknik Analisis Data}

Dalam menjawab rumusan masalah yang ada, peneliti akan melakukan beberapa tahapan sebagai berikut:

1. Menganalisis bisnis perusahaan dengan membuat flowchart dari persediaan. Flowchart ini tujuannya untuk mengetahui alur atau siklus persediaan yang ada di toko online sayur mayur.

2. Membandingkan hasil data/ wawancara dengan komponen pengendalian internal menurut COSO. Teknik analisis data yang digunakan dalam penelitian ini adalah deskriptif yaitu dengan memberi gambaran secara lengkap dari hasil penelitian. Metode memuat komponen utama meliputi; (1) jenis penelitian; (2) populasi dan prosedur pengambilan sampel; (3) pengukuran; dan (4) teknik analisis.

\section{HASIL DAN PEMBAHASAN}

Toko online sayur mayur didirikan pada tahun 2017. Toko online sayur mayur merupakan start up yang bergerak di bidang pertanian untuk menjual sayur dan buah melalui aplikasi online. 
Toko online sayur mayur ini tidak hanya menjual produk lokal saja. Namun, Toko online sayur mayor menjual sayur dan buah berupa organik, dan hidroponik. Untuk mendapatkan sayur dan buah tersebut, Toko online sayur mayur bekerja sama dengan petani langsung atau supplier yang berada di lembang. Jadi, produk Toko online sayur mayur ini langsung dari petani serta sayur dan buah ini sehingga sayur dan buah dalam kondisi segar pada saat diterima oleh konsumen.

Toko online sayur mayor didirikan ketika melihat kesulitan petani mencari akses untuk menjual hasil taninya ke konsumen. Pada saat itu petani hanya menjual hasil taninya ke pasar sekitar saja. Sehingga omset yang didapat sangat rendah. Berdasarkan kondisi tersebut, didirikan Toko online sayur mayur tersebut dengan misi utama membantu petani dalam menjual hasil taninya dan meningkatkan pendapatan petani tradisional.

Analisis sistem pengendalian internal Toko Online Sayur Mayur didasarkan pada standar COSO, 2013 yang terdiri dari lima komponen yaitu lingkungan pengendalian, penilaian risiko, aktivitas pengendalian, informasi dan komunikasi, dan pemantauan. Analisis dilakukan disetiap komponen tersebut untuk melihat kesesuaian antara praktek yang dilakukan dengan standar cosO.

\section{Lingkungan Pengendalian}

Lingkungan pengendalian dapat menciptakan suatu organisasi yang mempengaruhi kesadaran personal tentang pengendalian.

a Komitmen terhadap integritas dan nilai etika. Adanya komitmen terhadap integritas dan nilai etika yang baik. Bentuk integritas dan nilai etika yaitu penanganan keluhan oleh bagian customer service atau dalam menjawab pertanyaan dari konsumen mengenai persediaan sayur dan buah. Permasalahan maupun keluhan terhadap produk langsung ditanggapi dengan cepat dancustomer service berusaha untuk menyelesaikan keluhan dengan baik, sesuai dengan prosedur yang ada dan kewenangan yang dimiliki. Komitmen terhadap integritas dan etika tercermin pada filosofi perusahaan yang menjunjung tinggi kejujuran dan kerjasama.

b Dewan komisaris menunjukkan adanya independensinya terhadap manajemen dan melaksanakan pengawasan terhadap pengembangan dan kinerja pengendalian internal. Perusahaan sudah melaksanakan pengawasan dengan adanya inspeksi mendadak oleh Founder atau pihak terkait lainnya untuk melihat atau mengontrol pengendalian sudah dilakukan atau belum. Kegiatan monitoring dibutuhkan agar peluang untuk melakukan kecurangan dapat dikurangi.

c Manajemen membentuk pengawasan dari komisaris, struktur, jalur pelaporan, dan kewenangan serta tanggung jawab yang sesuai dalam upaya pencapaian tujuan organisasi. Perusahaan telah membagi tugas dan wewenang setiap karyawan dengan membentuk struktur organisasi. Pembagian tugas dan wewenangnya sesuai yang dibutuhkan perusahaan. Semakin berkembangnya perusahaan, cakupan tanggung jawab dan wewenang semakin luas sehingga diperlukan bentuk organisasi desentralisasi sebagai pengganti sentralisasi. Struktur organisasi yang dibentuk sudah sesuai dengan kebutuhan pelaksanaan kegiatan bisnis perusahaan dan juga alur tanggung jawab dan kewenangan.

d Perusahaan menunjukkan adanya komitmen untuk memperoleh, mengembangkan, dan memper-tahankan individu yang kompeten dalam upaya pencapaian tujuan organisasi.Perusahaan dalam merekrut karyawan memiliki komitmen tinggi melalui proses rekrutmenkaryawan yang dilihat dari pengalaman, wawancara dan tes kompetensi 
(misalnya kemampuan penggunaan aplikasi excel bagi pelamar unit tertentu). Tata kelola proses rekrutment karyawan telah dijalankan sesuai prosedur yang ditetapkan dalam rangka memperoleh karyawan sesuai dengan kebutuhan mendukungkegiatan bisnis perusahaan mencapai tujuan. Karyawan yang direkrut harus memiliki latar belakang pendidikan sesuai dengan bagian yang membutuhkan, juga kemampuan/ skill yang dimiliki karyawan.

e Menciptakan tata kelola baik dalam perusahaan melalui pelaksanaan pengendalian internal, perusahaan mewajibkan setiap individu untuk mengemban akuntabilitas atas tanggung jawabnya berkaitan dengan pencapaian tujuan perusahaan.Perusahaan telah mewajibkan setiap karyawan untuk bertanggung sesuai dengan posisi pekerjaan dan karyawan harus mampu menjelaskan setiap kondisi yang berhubungan dengan tanggung jawabnya terkait pengendalian internal atas persediaan sayur dan buah.

\section{Penilaian Resiko}

Penilaian resiko merupakan kegiatan yang dilakukan oleh manajemen dalam mengidentifikasi dan menganalisis resiko yang menghambat perusahaan dalam mencapai tujuan.

a. Perusahaan menetapkan tujuan secara jelas sehingga memungkinkan dilakukannya proses identifikasi dan penilaian risiko terkait dengan tujuan.

Perusahaan telah menetapkan tujuan secara jelas mengenai proses atau resiko yang telah teridentifikasi. Resiko yang teridentifikasi diantarannya:

1. Barang Cacat (Semi Waste)

2. Barang rusak (Waste)

b. Perusahaan mengidentifikasi risiko terkait dengan pencapaiantujuan organisasi pada seluruh lingkup entitas, dan menganalisis risiko sebagai dasar untuk menentukan bagaimana risiko-risiko tersebut harus dikelola.Perusahaan telah mengidentifikasi dan menganalisis setiap risiko yang akan terjadi. Risiko yang sudah terlihat yaitu risiko atas kerusakan atau kebusukan dari sayur dan buah dan perusahaan telah memiliki kebijakan dalam mengantisipasi dan mengurangi potensi risiko tersebut.

c. Perusahaan mempertimbangkan potensi terjadinya fraud dalam menilai risiko.

Perusahaan telah mempertimbangkan terjadinya fraud dalam menilai resiko. Di perusahaan ada barang semiwaste dan barang waste. Barang semiwaste yaitu dimana sayur atau buah tersebut hanya cacat sedikit seperti, ada warna hitam diluarnya atau kutu buah. Sehingga tidak bisa dikirim ke konsumen yang telah mengorder melalui aplikasi. Barang dagangan (persedian) dengan kondisi semiwastetersebut tidak dibuang dan masih layak makan dan memiliki nilai untuk dijual, maka kebijakan perusahaan untuk menjual kembali ke masyarakat dengan harga lebih murah (discount). Sedangkan barang waste yaitu barang yang sudah tidak layak dijual akan dimusnahkan.

Barang semiwaste yang dijual ke masyarakat, melalui pengontrolan terlebih dahulu. Jadi, setiap masyarakat yang membeli buah atau sayur wasteharus melalui proses pengecekan barang oleh satpam. Dengan cara mencocokkan barang yang ada dengan nota yang diterima oleh pembeli. Hal ini dilakukan untuk mengurangi terjadinya kecurangan.

d. Perusahaan mengidentifikasi dan menilai perubahan yang dapat mempengaruhi sistem internal control secara signifikan.

Perusahan telah mengidentifikasi dan menilai perubahan sistem pengendalian internal. Seperti, item yang belum siap dipanen akan diberitahu di aplikasi dan diberitahu tanggal pemanenan sayur dan buah tersebut. 


\section{Aktivitas Pengendalian}

Aktivitas pengendalian merupakan kebijakan dan prosedur. Kemungkinan terdapat banyak aktivitas pengendalian pada setiap entitas, termasuk pengendalian secara manual dan pengendalian secara otomatis.

Perusahaan telah menyeleksi dan membangun aktivitas pengendalian yang mendukung upaya mitigasi risiko sehingga risiko berada pada level yang dapat diterima. Perusahaan telah melakukan aktivitas pegendalian dalam mengatasi resiko. Aktivitas yang telah dilakukan adalah melakukan perhitungan fisik atau stock opname setiap 6 bulan sekali. Bagian gudang akan melakukan perhitungan sayur dan buah yang ada di gudang dan dicatat di kartu perhitungan fisik, lalu melakukan rekap di daftar hasil perhitungan fisik dan mencocokan dengan jumlah sisa persediaan yang ada di gudang untuk mengetahui kesesuaian pencatatan persediaan. Saat ini, perusahaan belum membatasi karyawan atau siapapun yang masuk ke dalam gudang penyimpangan buah dan sayur. Hal ini akan menimbulkan resiko terhadap persyaratan derajat suhu, kekedapan udara terhadap sayur dan buah yang disimpan, serta potensi kehilangan sayur dan buah.

Perusahaan telah menyeleksi dan membangun aktivitas pengendalian umum dengan menggunakanteknologi untuk mendukung pencapaian tujuan organisasi. Dalam membangun aktivitas penendalian tersebut, perusahaan telah menggunakan teknologi untuk mendukung pencapaian organisasi, yaitu perusahaan telah memasang closed-circuit television (CCTV) di setiap sudut ruangan untuk menghindari kehilangan sayur dan buah, namun sayangnya, bagian gudang belum dipasang CCTV.

Perusahaan menerapkan aktivitas pengendalian sebagaimana tercermin pada kebijakan yang menetapkan apa yang diharapkan, dan dalam prosedur yang relevan untuk melaksanakan kebijakan. Perusahaan sudah melakukan pemisahan tugas sesuai dengan jobdesk masingmasing. Divisi itu tidak ditemukan adanyaperangkapan tugas, tugas dan tanggung jawab sudah sesuai dengan masing-masing divisi.

\section{Informasi dan Komunikasi}

Tujuan dari sistem informasi dan komunikasi akuntansi suatu entitas adalah untuk memulai, mencatat, memproses dan melaporkan transaksi-transaksi yang terjadi dalam suatu entitas dan untuk menjaga akuntabilitas aset-aset yang terkait.

Organisasi mendapatkan informasi yang berkualitas dan relevan untuk mendukung fungsi seluruh komponen pengendalian internal. Informasi dan komunikasi sangat penting bagi perusahaan. Perusahaan selalu memberikan informasi terkait persediaan yang ada dalam aplikasi. Jika barang tersebut tersedia, maka akan langsung diinformasikan lewat aplikasi atau website perusahaan.

Organisasi mengkomunikasikan informasi secara internal, termasuk tujuan dan tanggung jawab pengendalian internal yang diperlukan untuk mendukung fungsi pengendalian internal. Setiap ada perubahan informasi mengenai jadwal pertemuan, ada pembaharuan sistem, masuknya item baru dan sebagainya selalu diinformasikan dan dikomunikasikan oleh pihak terkait agar tidak terjadinya simpang siur mengenai informasinya.

Organisasi berkomunikasi dengan pihak luar mengenai hal terkait dengan berbagai hal yang dapat mempengaruhi berfungsinya seluruh komponen pengendalian. Perusahaan dapat berkomunikasi dengan pihak luar terkait persediaan. Seperti,berkomunikasi dengan supplier bahkan dengan kompetitor yang sejenis. 


\section{Pengawasan}

Aktivitas pengawasan berkaitan dengan penilaian yang berjalan atau penilaian berkala atas kualitas pengendalian internal oleh manajemen untuk menentukan bahwa pengendalian dijalankan sesuai dengan tujuannya.

Organisasi memilih, mengembangkan, dan melakukan evaluasi berkelanjutan secara terpisah untuk memastikan komponen pengendalian internal telah berfungsi dengan baik. Perusahaan melakukan evaluasi secara terpisah sesuai dengan divisi. Agar kekurangan yang ada pada divisi tersebut bisa dievaluasi.Organisasi memilih, mengembangkan, dan melakukan evaluasi berkelanjutan secara terpisah untuk memastikan semua komponen pengendalian internal berfungsi baik.

Organisasi mengevaluasi dan mengkomunikasikan kekurangan pengendalian internal secara tepat waktu kepada pihak-pihak yang bertanggungjawab untuk mengam-bil tindakan korektif termasuk manajemen senior dan dewan direksi. Perusahaan dapat mengevaluasi dan mengkomunikasikan kekurangan dalam pengendalian internal. Kekurangan yang ada diharapkan dapat diperbaiki, seperti halnya, mengenai penentuan harga sayur dan buah. Ketika, harga sayur dan buah yang ditetapkan oleh perusahaan lebih tinggi dibandingkan kompetitor lain, maka harus diadakan evaluasi atau tindakan untuk mengetahui penyebab harga yang ditetapkan tersbut lebih tinggi dibanding dengan kompetitor. Harga yang lebih tinggi dari pesaing akan memberikan dampak yang kurang baik seperti tidak dapat bersaing, penurunan tingkat penjuanlan.

\section{KESIMPULAN}

Berdasarkan hasil penelitian danpembahasan yang telah dijelaskansebelumnya, dapat disimpulkan bahwa praktek sistem pengendalian internal yang diterapkan oleh perusahaan sudah memenuhi standar Commite of Sponsoring Organization (COSO). Namun ada satu komponen yang belum memenuhi standar COSO yaitu aktivitas pengendalian. Karena masih kurangnya pengendalianinternal pada aktivitas pengendalian terhadap persediaan yang diuraikan sebagai berikut:

Pertama, belum terpasang CCTV pada bagian gudang. Sehingga mengakibatkan potensi timbulnya kehilangan, kecurangan, dan sebagainya terhadap persediaan.Persediaan merupakan aset terpenting dalam perusahaan.

Kedua, tidak adanya ketentuan tentang pembatasan atau larangan bagi karyawan yang tidak berkepentingan/bertugas untuk masuk ke gudang. Hal ini mengakibatkan kedapnya udara yang mengakibatkan udara bagi sayur dan buah menjadi berkurang. Sayur dan buah, membutuhkan udara dan suhu yang cukup maksimal agar tidak mudah layu, busuk, dan sebagainya.

\section{Implikasi}

Berdasarkan kesimpulan yang telah diuraikan sebelumnya, maka disarakan sebagai berikut: pertama, perusahaan disarankan untuk memasang CCTV di bagian gudang sebagai alat untuk melakukan control terhadap aktivitas yang ada dalam gudang penyimpanan. Kedua, perusahaan sebaiknya membuat aturan/peraturan tentang pembatasan orang/karyawan yang keluar masuk gudang penyimpanan. Ketiga, sebagai pelaksanaan sistem perencanaan dan pengendalian manajemen perusahaan disarankan agar memperbaiki sistem pengendalian internal yang masih belum sesuai dengan standar COSO dan secara rutin 
melakukan evaluasi kembali, walaupun sistem pengendalian internal sudah dilaksanakan sesuai dengan prosedur yang ada.

\section{Keterbasan dan Saran}

Studi dan literatur sejenis yang meneliti tentang pengendalian internal pada perusahaan start upmasih jarang ditemukan di Indonesia mengingat praktek e-commerce merupakan bisnis yang baru muncul beberapa tahun belakangan ini, sehingga disarankan agar peneliti lainnya melakukan penelitian yang sama, terutama pengendalian internal persedian untuk produk sayur mayur. Ditinjau dari pendekatan atau metode yang digunakan pada studi ini, disarankan untuk penelitian selanjutnya menggunakan penelitian empiris sehingga hasil penelitian dapat digunakan dalam melakukan generalisasi.

\section{REFERENSI}

Agustina, T. S. (2011). Peran Inkubator Bisnis Perguruan Tinggi Dalam Meminimalkan Resiko Kegagalan Bagi Wirausaha Baru Pada Tahap Awal (Start-up).Jurnal Ekonomi dan Bisnis Airlangga (JEBA)| Journal of Economics and Business Airlangga No. 21.

Amanda, C. Sondakh, Jullie J. dan Tangkuman, Steven J. 2015). Analisis Efektivitas Pengendalian Internal Atas Persediaan Barang Dagang Pada Grand Hardware Manado. JURNAL EMBA: JURNAL RISET EKONOMI, MANAJEMEN, BISNIS DANAKUNTANSI, Vol.3 No.3.

Darsana, L., SP, W., \& Wahyuti, T. (2003). Pengaruh Saat Panen Dan Suhu Penyimpanan Terhadap Umur Simpan Dan Kualitas Mentimun Jepang.Agrosains 5(1):1-12.

Devlin, R. (1977). Plant Pysiology. 3rded. D. Van Nost

Gardjito, M., \& Reni, Y. S. (2012). Fisiologi Pascapanen Buah \& Sayur. UGM Press. Yogyakarta. Indrajani. (2011). Perancangan Basis Data dalam all in 1. Elex Media Komputindo. Jakarta.

Jhon David H, S., \& Kilmanun, J. C. (2016). Penanganan Pasca Panen Penyimpanan untuk Komoditas Hortikultura.Prosiding Seminar Nasional Inovasi Teknologi Pertanian.

Kotler, P., \& Armstrong, G. (2012). Principles of Marketing. Pearson Education Limited. England. Manahan. (2018). Manajemen Operasi \& Rantai Pemasok (Pertama).Mitra Wacana Media. Jakarta

Mulyadi. (2013). Sistem Informasi akuntansi. Edisi Ketiga. Salemba Empat. Jakarta.

Rahayu, S. Tri, Asgar, A., \& Hidayat, I. M. (2013). Evaluasi Kualitas Beberapa Genotipe Bayam Pada Penanaman Di Jawabarat. Berita Biologi : Jurnal Ilmu-ilmu Hayati. Vol. 12 No. 2.

Sekaran, U. (2016). Metode Penelitian Untuk Bisnis (6th ed.). Salemba Empat. Jakarta Sugiyono. (2017). Metode Penelitian Kuantitatif, Kualitatif Dan R\&D. Alfabeta. Bandung.

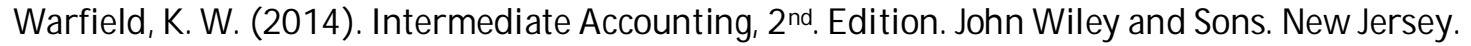




\section{Declarations}

\section{Funding}

The authors received no financial support for the research and publication of this article.

\section{Conflicts of interest/ Competing interests:}

The authors have no conflicts of interest to declare that are relevant to the content of this article.

\section{Data, Materials and/ or Code Availability:}

Data sharing is not applicable to this article as no new data were created or analyzed in this study.

\section{About the Authors \\ Regita M Farhana adalah mahasiswa Universitas Trilogi Fakultas Ekonomi dan Bisnis Program Studi Akuntansi angkatan 2016 dan telah menyelesaikan studinya pada tahun 2019. Ketertarikan pada topik pengendalian internal membawa ybs meneliti mengenai penerapan pengendalian internal di suatu perusahaan start up sebagai tugas akhir. Email yang dapat dihubungi : reregita@gmail.com \\ Ludwina Harahap adalah dosen Prodi Akuntansi Fakultas Ekonomi Universitas Trilogi, denganpengalaman mengajar program sarjana di bidang Akuntansi Manajemen, Pengendalian Manajemen,Akuntansi Keuangan, dan beberapa matakuliah akuntansi perilaku lainnya. Penulis memilikiketertarikan pada penelitian akuntansi manajemen dan perilaku. Sebagai coresponding author, email yang dapat dihubungi di:ludyhara@trilogi.ac.id.}

\section{How to cite this Article}

Farhana, R., \& Harahap, L. (2020). Pengendalian Internal Pada Perusahaan Start Up. AKURASI: Jurnal Riset Akuntansi Dan Keuangan, 2(3), 137 - 148. Retrieved from https:// ejournal.imperiuminstitute.org/ index.php/ AKURASI/ article/ view/ 242 